Yayın Geliş Tarihi: $\quad 30.09 .2017$

Yayın Kabul Tarihi: 21.03 .2018

Online Yayın Tarihi: 20.04.2018
Dokuz Eylül Üniversitesi İktisadi ve İdari Bilimler Fakültesi Dergisi Cilt:32, Sayı:2, Yıl:2017, ss. 163-195

\title{
Küresel Kapitalizmin Sosyalleştirilen Yüzü: Birleşmiş Milletler 2015 Sonrası Kalkınma Gündemi Örneği
}

\author{
Merve KAYADUVAR ${ }^{1}$
}

\author{
İlteriș ERGUN ${ }^{2}$
}

$\ddot{O} z$

BM’nin 2013 yılında yayınlanan "Yeni Bir Küresel Ortaklı: Sürdürülebilir Kalkınma Yoluyla Yoksulluğu Ortadan Kaldırmak ve Ekonomileri Dönüştürmek” raporu 2015 sonrası yeni hedefleri, bu bă̆lamda 2030 yılına kadar aşırı yoksulluğu ortadan kaldırmak ve sürdürülebilir kalkınma sözünü yerine getirmek için evrensel bir gündemi ortaya koyuyor. Bu çalışmada bu hedeflerin temelini küresel kapitalizmin doğasının yarattı̆̆ sosyal tahribatların görünürlüğ̈̈nü azaltarak kapitalist sistemin sürdürülebilirliğini sağlamayı amaçlayan Post-Washington uzlaşısının oluşturduğu ve hedeflerin sürdürülebilir kalkınma adı altında sürdürülebilir bir kapitalist sistemi amaçladı̆̆ tartışılmaktadır. Küresel kapitalizme sosyal bir taraf kazandırma amacı bağlamında, açıklanan hedefler ile sosyal sorunların özellikle yoksulluğun görünürlüğ̈̈nü azaltılmaya çalışılmakta ama yoksulluğun sisteme içkin temel sebeplerine vurgu yapılmamaktadır.

Anahtar Kelimeler: Yoksulluk, Sürdürülebilir Kalkınma, Post-Washington Uzlaşısı.

JEL Sinıflandırma Kodları: I32, Z13.

\section{The Socialized Face of Global Capitalism: The Case of Post-2015 Development Agenda of United Nations}

\begin{abstract}
The report of UN published in 2013 "A New Global Partnership: Eradicate Poverty and Transform Economies through Sustainable Development" reveals the new post-2015 goals. The report sets forth a universal agenda to fulfil the promises of eradicating extreme poverty and sustainable development. In this study, it is argued that the Post-Washington consensus which aims to provide sustainability of the capitalist system by decreasing the appearance of social destructions stemming from the nature of the global capitalism forms the basis of the goals of UN and these goals target a sustainable capitalist system under the name of sustainable development. In the context of the aim for giving a social face to global capitalism, through these goals the appearance of social problems especially poverty is tried to be decreased however the fundamental reasons inherent to the system are not underlined.
\end{abstract}

Keywords: Poverty, Sustainable Development, Post-Washington Consensus.

JEL Clasification Codes: I32, Z13.

\footnotetext{
${ }^{1}$ Araş. Gör., Dokuz Eylül Üniversitesi, İktisadi ve İdari Bilimler Fakültesi, Kamu Yönetimi Bölümü, mervekayaduvar@gmail.com

2 Araş. Gör., Dokuz Eylül Üniversitesi, İktisadi ve İdari Bilimler Fakültesi, Kamu Yönetimi Bölümü, ilterisergun48@gmail.com
} 


\section{GíRIŞ}

\section{M.KAYADUVAR - İ.ERGUN}

Yirminci yüzyıl birçok ekonomik ve sosyal değişimin yaşandığ tarihin en zengin dönemi diyebileceğimiz bir yüzyıldı ama aynı zamanda yoksulluğun, gelir eşitsizliklerinin, işsizliğin de çok yüksek seviyelere çıktığı bir dönem oldu. Şu an yaşadığımız dönem geçtiğimiz yüzyılın ortaya çıkardığı bu sorunların hem kronikleştiği hem de çözüm arayışlarının yoğunlaştığı bir dönem olarak ifade edilebilir.

Küreselleşmenin tam olarak kendini gösterdiği bu dönemde hızla ilerleyen teknolojinin, finansal hareketliliklerin, ulaşım ve iletişim imkanlarının zenginliğinin yanı sıra "küreselleşmenin öteki yüzü” (Şenses, 2009: 13) olarak yoksulluk tüm dünyada sadece gelişmekte olan değil gelişmiş ülkelerde de etkisini yoğun bir şekilde göstermeye başladı. Bu nedenle küreselleşme zengini daha zengin, yoksulu da daha yoksul yapmaktan başka bir işe yaramadığ 1 şeklinde eleştirilmeye başladı (Kongar, 2001: 32-33). Aslında yoksulluk azgelişmişlik sorunu olarak tanımlansa da tüm dünyayı etkisi altına alan neoliberal politikalar işsizlik, yoksulluk ve gelir eşitsizliklerinin gelişmiş kapitalist ülkelerde de tarihte yaşanan en yüksek oranlara çıkmasına sebep oldu. Neoliberal politikaların yoğun olarak uygulandığı 1980'li yıllarda dünya nüfusunun yüzde 44'ü (1.99 milyar insan) günlük 1.90 dolardan daha az bir gelirle hayatını sürdürmek zorundayd1. $\mathrm{Bu}$ durum tüm dünyada yoksulluk konusuna olan ilgiyi artırmış hem uluslararası kuruluşlar hem de akademi yoksulluk araştırmalarına daha çok eğilmeye başlamıştır. Yoksulluk konusunda Birleşmiş Milletler (BM) ve Birleşmiş Milletler'in yoksullukla mücadele konusunda temel kurumu olan Birleşmiş Milletler Kalkınma Programı (UNDP) ve özellikle de BM'nin özerk uzman kuruluşu olan Dünya Bankası (DB) ön plana çıkmaktadır öyle ki Dünya Bankası yoksulluk tartışmalarının ve politika eğilimlerinin en önemli belirleyicisi haline gelmiştir (Dertli, 
2007). Yoksulluk konusu 1970’lerin sonundan itibaren Dünya Bankası'nın yıllık kalkınma raporlarının birçoğunda ana gündem maddesi olmuş ve her onuncu yılın kalkınma raporu yoksulluk konusuna ayrılmıştır. Birleşmiş Milletler ise yoksulluğun uluslararası gündemde yoğun olarak tartışıldığı 1990’lardan itibaren yoksullukla mücadele konusunda çok önemli bir rol oynamıştır. Bu nedenlerden dolayı yoksulluk problemini ve bu konuda ön plana çıkartılan çözüm önerilerini kavrayabilmek için Dünya Bankası'nın ve Birleşmiş Milletlerin yoksulluğu nasıl kavramsallaştırdığını ve çözümlerini hangi temellere dayandırdığgnı incelemek gerekir.

Bu çalışmanın amacı Birleşmiş Milletler'in 2013 yılında yayınlanan ve 2015 sonrası yeni hedefleri ortaya "Yeni Bir Küresel Ortaklık: Sürdürülebilir Kalkınma Yoluyla Yoksulluğu Ortadan Kaldırmak ve Ekonomileri Dönüştürmek" raporunu eleştirel bir açıdan incelemek ve bu hedeflerin temelini küresel kapitalizmin doğasının yarattığı sosyal tahribatların görünürlüğünü azaltarak kapitalist sistemin sürdürülebilirliğini sağlamayı amaçlayan Post-Washington uzlaşısının oluşturduğunu ve hedeflerin sürdürülebilir kalkınma adı altında sürdürülebilir bir kapitalist sistemi amaçladığını tartışmaktır.

$\mathrm{Bu}$ bağlamda, girişin ardından ikinci bölümde yoksulluk neoliberal dönüşüm bağlamında Dünya Bankası ve Birleşmiş Milletler'in kavramsallaştırmaları üzerinden tartışılacak, iki farklı perspektifi temsil ettikleri literatürde sıkça ifade edilen Dünya Bankası'nın ve Birleşmiş Milletler'in aslında temelde yoksulluğu kapitalist sistem bağlamından kopartarak kavramsallaştırdığı gösterilmeye çalış1lacaktır. Sonraki bölümde Washington Uzlaşısı ve Sosyalleştirilen kapitalist sistem bağlamında PostWashington Uzlaşısı eleştirel bir bakış açısıyla incelenecek ve dördüncü bölümde BM 2015 Sonrası Kalkınma Gündemi’nin temelini Post- 


\section{M.KAYADUVAR - İ.ERGUN}

Washington Uzlaşısı'nın oluşturduğu tartışılacaktır. Son olaraksa sonuç bölümünde genel bir değerlendirme yapılacaktır.

\section{NEOLİBERAL DÖNÜŞÜM BAĞLAMINDA YOKSULLUK}

Yoksulluk tarihin her döneminde kendini göstermiş ve çeşitli düzeylerde ilgi görmüş bir olgudur. Ulusal ya da yerel düzeylerde olduğu gibi son yıllarda küresel düzeyde de yoğun bir şekilde ele alınmaktadır. Yoksulluğa ilişkin bu ilgi çok eskilere dayanmaktadır öyle ki kökenlerini 1600lü yıllardan itibaren izlemek mümkündür (Şenses, 2009). 18. Yüzyılın ortalarından itibaren sanayi devrimine dayanan kapitalist ekonominin gelişmesiyle birlikte kitlesel yoksulluk ortaya çıkmaya başladı ve önemli kuramcılar ve yazarlar yoksulluk ve toplumsal bölüşüm konularına daha çok ilgi göstermeye başladılar. Ama yoksulluğa özellikle 1850'den sonra kilisenin, sendikaların, vakıfların, yardım kuruluşlarının ve başta edebiyatçılar olmak üzere sanatçıların ilgisi arttı. Yoksulluk siyasal düzlemde de ön plana çıkartılan bir konu haline geldi. Örneğin 1834 yılında İngiltere'de çıkartılan “Yeni Yoksullar Yasası” yoksulluk olgusu açısından bir dönüm noktası oldu (Buğra, 2008). Özellikle 1929 yılında yaşanan Büyük Buhran sonrasında ortaya çıkan kitlesel işsizlik ve yoksulluk bu sorunlara yönelik ilginin artmasına sebep oldu (Şenses, 2009). ABD başta olmak üzere gelişmiş kapitalist ülkelerde krizden çıkışın yolu olarak devlet müdahalesi ön plana çıktı. İkinci Dünya Savaşı sonrası hızlanacak refah devleti uygulamalarının temelleri 1929 krizi sonrası dönemde yavaş yavaş atılmaya başladı.

Kapitalizmin 'Altın Çağı' olarak adlandırılan savaş sonrası dönemde özellikle gelişmiş kapitalist ülkelerde hızlı sanayileşme ve eğitimin, sağlı̆̆ın devlet tarafindan karşılanması, işsizlik sigortası gibi sosyal haklar ve sosyal yardımlar gibi refah devleti uygulamaları ile yoksulluk görece azaldı. Ama 
refah devleti bağlamında ortaya çıkan bu sosyal politikaların merkezinde yoksullukla mücadele olgusu değil bireyleri hak temelli bir "vatandaşlık statüsü” altında birleştirme amacı yer alıyordu (Buğra, 2008: 66). Özellikle gelişmiş kapitalist devletlerin vatandaşlık temelinde hak olarak sunduğu sosyal politikalar ile yoksulluk olgusunun görünürlüğünün azalması sonucu yoksulluğun gelişmemiş ülkelerin bir sorunu olduğu düşüncesi ön plana çıktı. Şenses'in de ifade ettiği gibi bu dönemde yoksulluk 'azgelişmişlik' olgusuyla özdeştirilmeye başladı (2009). Savaş sonrası dönemde ayrı bir akademik disiplin olarak ortaya çıkan 'kalkınma iktisadı', azgelişmişliğin çözümünü devlet tarafından koordine edilen büyük ölçekli sanayi yatırımları ve temel sektörlerde üretimin devlet tarafından gerçekleştirilmesi ile hızlı sanayileşme ve altyapı yatırımlarının artırılmasına dayalı hızlı büyüme olarak ortaya koymuştur (Saad-Filho, 2010; Şenses, 2009; Uzun, 2003). Kalkınma iktisadında yoksulluk ve toplumsal bölüşüm göz ardı edilip, hızlı büyümenin uzun vadede toplumun bütününe yayılacağına ve yoksulluk probleminin çözüleceğine dair büyüme getirilerinin aşağı damlama etkisi (trickle down effect) düşüncesi hakimdi (Saad-Filho, 2010; Karaçay, 2016; Stiglitz, 2007). Bir başka deyiş ile Saad-Filho’nun da ifade ettiği gibi yoksulluğun azaltılması büyümenin dolaylı bir sonucu olarak kabul ediliyordu (2010). Ama yoksulluğun uzun vadede büyümenin etkisiyle çözüleceği düşüncesi 1960’ların ortalarından itibaren ciddi eleştiriler almaya başladı çünkü hızlı ekonomik büyümeye karşı hala az gelişmiş ülkelerde yoksulluk çok yüksek seviyelerde seyrediyordu (Şenses, 2009) ve gelir eşitsizlikleri hızlı sanayileşme ve ekonomik büyümeye rağmen azalmamıştı. İronik bir şekilde bu eleştiriler neo-klasik iktisatçılar tarafından yapılıyordu. Neo-klasik iktisatçılar devlet müdahalesinin yoğun olduğu ithal ikamesine dayalı korumacı sanayileşme politikalarının piyasanın kendi iç 


\section{M.KAYADUVAR - İ.ERGUN}

dinamiklerine göre işlemesine engel olarak yoksulluğa ve gelir eşitsizliklerine yol açtığını iddia ediyorlardı.

Sorunların kaynağı olarak görülen içe dönük ithal ikamesine dayalı sanayileşme stratejisinin dışa açı ihracata dayalı ekonomik model ile değiştirilerek yoksulluk ve gelir eşitsizliği sorunlarının çözüleceği düşüncesi 1970’lerde iyice güç kazanmaya başladı. Çünkü 1970’lerin başında yaşanan yapısal krizin etkisiyle sadece az gelişmiş ülkelerde değil gelişmiş kapitalist ülkelerde de gelir eşitsizlikleri ve yoksulluk artan kitlesel işsizlikle birlikte çok yüksek oranlara ulaştı. Yaşanan petrol şoku ve yapısal krizin doğurduğu ekonomik durgunluk ve enflasyon (stagflasyon) kar oranlarının düşmesine ve birikim rejimi krizine neden oldu. Bu ortamda eski sanayileşme stratejisi sürdürülebilir değildi ayrıca refah devleti harcamaları da ağır eleştiriler altındaydı. Refah devletinin gerektirdiği kamu harcamaları dışa kapalı, hızlı sanayileşme döneminde sürdürülebilirken dışa açık ekonominin gerektirdiği yapısal rekabet için bir engel oluşturuluyordu. Diğer bir ifadeyle savaş sonrası dönemde yüksek kamu harcamalarının finansmanı yüksek vergiler ile karşılanıyorken bu vergiler uluslararası piyasalarda rekabet eden firmalar için 'üretken olmayan maliyet' olarak görülmeye başlandı (Jessop, 2002). $\mathrm{Bu}$ gelişmeler 1şığında ithal ikameci sanayileşme stratejisi daha fazla sürdürülebilir değildi ve 1970’leri sonuna doğru neo-klasik iktisata dayalı neoliberal politikalar gelişmiş kapitalist ülkelerde 'Başka Alternatif Yok' sloganıyla uygulanmaya başladı. Neoliberal politikalar Uluslararası Para Fonu (IMF) ve Dünya Bankası aracılığıyla gelişmekte olan ülkelere ihraç edildi. Korumacı, ithal ikamesine dayalı sanayileşme stratejisi ve devlet müdahaleleri yerini dışa açık, ihracata dayalı, serbest piyasa ekonomi modeline bıraktı. Yeni ekonomi modeli özelleştirmeler, esneklik, kuralsızlaştırma, finansal ve ticari serbestlik gibi neoliberal politikalara dayaniyordu. 
$\mathrm{Bu}$ gelişmelere paralel bir şekilde, Dünya Bankası Başkanı McNamara'nın 1973 yılındaki Nairobi toplantısında ortaya koyduğu gibi savaş sonrası dönemde uygulanan sanayileşme modelinin gelir eşitsizliklerini artırması ve yoksulluk sorununa çözüm sağlayamaması nedeniyle kalkınma politikalarında yoksulluğa özel bir vurgu yapılması gerekliliği ön plana çıktı (Karaçay, 2016) ve bu bağlamda Dünya Bankası 1970’lerin başında yoksulluk sorununu kalkınma gündeminin başına aldı.

Dünya Bankası'nın yoksulluğa ilişkin artan ilgisini neoliberal politikaların sebep olduğu sosyal tahribatlara karşı oluşacak toplumsal memnuniyetsizlikleri engelleme amacıyla ilişkilendirebiliriz. Özgür'ün de dediği gibi "[t]arihsel olarak kitlesel yoksullaşma süreçlerinde yoksulluk, bizatihi yoksullaştıranların ideolojik söyleminin bir unsuru, politik ve ekonomik yeniden yapılanma programlarının bir dinamiği haline” gelebilmektedir (2004: 321). Benzer bir şekilde, Şenses Dünya Bankası'nın yoksulluğa karşı bu artan ilgisini hakim güçler yaklaşıma bağlamakta ve DB'nin ana finansörlerinin özellikle Amerika olmak üzere gelişmiş kapitalist devletler olmasından dolayı Dünya Bankası'nın bu ülkelerin bakış açılarını ve çıkarlarını uluslararası düzeyde savunma işlevine sahip olduğunu ifade etmektedir (2009). Bu noktadan hareketle, DB'nin yoksulluk konusuna olan yaklaşımı neoliberal yaklaşımının ayrılmaz bir parçasıdır, neoliberal yaklaşımıyla büyük bir tutarlılık gösterir ve bu nedenle de uluslararası düzlemde gelişmiş ülkelerin çıkarlarını koruma işlevini desteklemektedir (Şenses, 2009). Şenses'e paralel bir şekilde Zapçı da Dünya Bankası'nın yoksulluğu sona erdirmek gibi bir hedefi olmadığını, doğasının bir gereği olarak böyle bir hedefi olamayacağını ve DB'nin yoksulluk programının yoksulluğu azaltmayı amaçlayan bir programdan çok siyasi bir program olduğunu ve toplumsal hoşnutsuzlukların sebep 


\section{M.KAYADUVAR - İ.ERGUN}

olabileceği radikal siyasal değişimleri engellemeyi amaçladığını ifade etmektedir (2002).

Özetle, Dünya Bankası'nın bir sonraki bölümde detaylı bir şekilde incelenecek olan Washington uzlaşısı bağlamında gelişmekte olan ülkelere dayatılan neoliberal politikaları destekleyen bir yoksulluk gündemini ön plana çıkarttığını ifade edebiliriz. Bu bağlamda yoksulluk kişisel bir problem olarak kavramsallaştırılmakta ve yoksulluk, yoksulların piyasa ile kurdukları bağın zayıflığı, düşük eğitim düzeyleri, sağlık yetersizlikleri, niteliksizlikleri veya beceri düzeylerinin düşüklüğü ile açıklanmaktadır (World Bank, 1978). Bu şekilde kavramsallaştırılarak yoksulluğun kapitalist sisteme içkin bir sorun olduğu gerçeği örtülmekte, yoksulluğun nedenleri neoliberal politikalarda aranmak yerine kişisel yetersizliklere indirgenmekte bu şekilde kapitalist sisteme yönelik oluşabilecek meşruiyet krizi engellenmeye çalışılmaktadır. Dünya Bankası'nın yoksulluk kavramsallaştırması bu soruna karşı geliştirilecek çözümlerde yoksulluğun sisteme içkin doğasından bağımsız bir şekilde sadece görünümüne odaklanmasını sağlamaktadır.

Dünya Bankası'nın 1978 yılı Dünya Kalkınma Raporu'na göre yoksullukla mücadelede ekonomik büyüme temel olmakla birlikte yoksulların üretkenliklerinin artırılması ve kamu hizmetlerinin yeniden düzenlenmesi merkezi bir öneme sahiptir. Buradan hareketle banka yoksullukla mücadeleyi istihdam edilebilir durumda olan yoksulların piyasaya entegre edilmesi üzerine kurmaktadır. Ekonomik büyüme yeni yatırımlar yaratacak ve bu şekilde istihdam olanakları artacaktır. Böylece çalışabilir durumdaki yoksullar para kazanacakları fırsatlar elde edeceklerdir. Ekonomik büyüme yaşam standartlarının yükselmesini sağlarken ayrıca kamu hizmetlerinin yeniden düzenlenmesi için gerekli kaynakların yaratılmasını sağlayacak, yoksulların piyasayla 
Dokuz Eylül Üniversitesi İktisadi ve İdari Bilimler Fakültesi Dergisi Cilt:32, Sayl:2, Yll:2017, ss. 163-195

ilişkilendirilmelerinin önündeki engeller bu şekilde kaldırılacak örneğin eğitim düzeylerinin düşüklüğü, sağlık yetersizlikleri gibi. 1978 raporunun bir diğer önemli vurgusu ise yoksulluğun mutlak yoksulluk üzerinden kavramsallaştırılmasına ilişkindir. Banka yoksulluğu az gelişmiş ülkelerin mutlak yoksulluk sınırında (günlük 1 dolar) yaşayan toplumsal kesimlerine indirgeyerek çözümü bu kesimlerin gelirlerinin piyasaya entegre edilerek artırılması olarak belirlemiştir. Göreli yoksulluk veya toplumsal gelir eşitsizlikleri göz önüne alınmamaktadır.

Dünya Bankası 1980 yılı raporunu da yoksulluk konusuna ayırmıştır ve temel olarak 1978 raporundaki yaklaşımını sürdürmüştür. 1980’li yıllar Dünya Bankası'nın Washington Uzlaşısı kapsamında yapısal uyum programlarıyla gelişmekte olan ülkelere neoliberal politikaları ihraç ettiği bir dönem olmuştur. $\mathrm{Bu}$ dönemde banka 1980 raporunu yoksulluğa ayırmasına rağmen yoksulluk konusunda ciddi bir eylemde bulunmamış yoksullukla mücadelede dişa açık ekonomiye geçiş vurgusu yapmıştır. Yapısal uyum programlarıyla birlikte sağlanacak ticari serbestleşmenin kaynakların tarım gibi emek yoğun sektörlere yöneltilmesi sağlanacak bu şekilde yoksulluk azaltılacaktır (Şenses, 2009). Bu dönemde yoksulluk ülkelerin iç problemi olarak kabul edilmiş ve 1990 yılına kadar Dünya Bankası'nın gündeminden çıkartılmıştır.

1980’li yıllar IMF’nin kısa dönemli istikrar politikalarına, Dünya Bankası'nın ise orta ve uzun vadede neoliberal dönüşümü sağlayacak ticari ve finansal serbestleşme, özelleştirmeler gibi yapısal uyum politikalarına odaklandığı bir dönem olmuştur. IMF ve Dünya Bankası tarafından istikrar ve yapısal uyum programları kapsamında uygulanan neoliberal politikalar var olan gelir eşitsizliklerini azaltmak bir yana milyonlarca insanın yoksullaşmasına, yolsuzlukların artmasına, gelişmekte olan ekonomilerin derin finansal krizlere girmesine ve buna bağlı olarak artan gelir 


\section{M.KAYADUVAR - İ.ERGUN}

adaletsizliklerine neden oldu. Bu durum Dünya Bankası'nı bir zorunluluk olarak yoksulluk konusuna odaklanmak zorunda bıraktı (Köse, 2004). Her onuncu yıl dünya kalkınma raporunu yoksulluk konusuna ayırma kararı alan Dünya Bankası, 1990 y1lındaki raporunda uzun zaman aradan sonra yoksullukla mücadele konusuna odaklandı ve yapısal uyum politikalarının yoksulluk üzerindeki negatif etkilerini itiraf etti. Banka, altyapıya yatırım ve açık ekonomi yoluyla emek yoğun büyüme ile sağlık ve eğitimle ilgili yoksullara temel hizmetlerin sağlanması olarak ifade edilen iki parçalı bir strateji ortaya koydu (Şenses, 2009). Getirdiği piyasa dostu çözüm önerilerinden hareketle Dünya Bankası'nın 1980 öncesi dönemindeki söylemlerine geri döndüğü ve temelde bir yenilik sağlamadığı söylenebilir (Şenses, 2009).

Dünya Bankası'nın yanı sıra 1990'larda Birleşmiş Milletler'in de yoksulluk konusuna olan ilgisi artmış ve 1990’lı yıllar yoksulluğun küresel bir gündem haline geldiği bir dönem olmuştur. Öyle ki BM, 1992'de 17 Ekim tarihini "Yoksulluğun Yok Edilmesi Uluslararası Günü” olarak, 1996 yılını ise "Yoksulluğun Yok Edilmesi Uluslararası Y1lı" olarak ilan etmiştir. Birleşmiş Milletler'in yoksullukla mücadele konusunda merkezi bir rol üstlenmesinde 1995 yılında Kopenhag'da gerçekleştirilen “Toplumsal Kalkınma Dünya Zirvesi” temel bir öneme sahiptir. Bu zirvede serbest piyasa ekonomisi verili olarak kabul edilerek yoksullukla bir zorunluluk olarak mücadele edilmesi gerekliliği ortaya konmuştur. Dünya Bankası'ndan farklı bir şekilde zirvede yoksulluk günlük 1 doların altında yaşayan toplumsal kesimler üzerinden tanımlanmamış, toplumsal adalet, gelir eşitsizliklerine de vurgu yapılmıştır. $\mathrm{Bu}$ nedenle literatürde sıkça Dünya Bankası'nın ve Birleşmiş Milletlerin yoksulluk konusunda farklı yaklaşımlar sergiledikleri tartışılmaktadır. Ama BM zirvesinde yoksulluk ve gelir eşitsizlikleri konusunda gelişmiş ülkelerden gelişmekte olan ülkelere 
resmi kalkınma yardımları haricinde bir çözüm önerilmemiştir (Özdek, 2002). Bu çerçevede, Birleşmiş Milletler'in de yoksulluğun kapitalist sistemden bağımsız olarak kavramsallaştırdığını, sisteme içkin nedenlerine odaklanmadığını ve çözümlerini de yoksulluğun görünümünün azaltılmasına odakladığını ifade edebiliriz. Bu nedenle DB'nin ve BM'nin iki farklı anlayışı sergilediklerini söyleyebilmek çok zordur. Birleşmiş Milletler DB gibi kendisini küresel kapitalizmin bir tarafı ve aracısı olarak görmese de küresel kapitalist sistemi veri olarak kabul ediyor ve sistemde yapısal değişiklik önermeden revize edilerek kötü etkilerinin azaltılabileceğini öne sürüyor (Tireli, 2009).

1990’lı yıllarda yoksulluğa ilişkin ilginin küresel düzeyde artması olumlu bir gelişme iken, bu konuda uluslararası politikaların belirleyicisi konumunda olan Dünya Bankası'nın ve Birleşmiş Milletler'in söylem düzeyinde güçlü olan yaklaşımları uygulamalar noktasında güçlü etkiler yaratamadi. 1990'lar neoliberal politikaların sebep olduğu sosyal tahribatların daha da arttı̆̆ı, IMF ve DB aracılığıyla gelişmiş ülkelerin çıkarları doğrultusunda küresel piyasalarla bütünleştirilen gelişmekte olan ülkelerin finansal krizlerle boğuştuğu bir dönem oldu. Bu durum neoliberal politikaların daha da eleştirilmesi sonucunu doğurdu ve kapitalist sistemin bir meşruiyet krizine sürüklenmesini önlemek için bir dizi politika değişikliği gündeme geldi. Çalışmanın üçüncü bölümünde kapitalist sistemin sürdürülebilirliğini sağlamak için yapısal uyum ve istikrar programları kapsamında uygulanan neoliberal politikaların insani bir çehreye kavuşturulması bağlamında ortaya çıkan Post-Washington Uzlaşısı incelenecektir.

\section{SOSYALLEȘTIRILEN KAPITTALİZM}




\section{M.KAYADUVAR - İ.ERGUN}

1980’li yıllar neoliberalizmin tüm dünyada etkisini gösterdiği, ekonomi yönetiminin ve devletin ekonomideki rolünün değiştiği yeni ekonomik ve sosyal bir düzenin kurumsallaştığı bir dönem oldu. Gelişmiş kapitalist ülkelerin kendi iç dinamikleri sonucu ortaya çıkan neoliberal politikalar, IMF'in destekleme kredisi anlaşmaları (stand-by aggrements) ve Dünya Bankası'nın yapısal uyum programlarıyla gelişmekte olan ülkelere ihraç edildi. Williamson 1989 'da 'Washington Uzlaşısı' kavramını ABD ve gelişmiş kapitalist ülkeler ile uluslararası finans kuruluşlarının arasındaki uzlaşmayı tanımlamak için kullanmıştır. Washington uzlaşısı kavramı ilk başlarda uluslararası finans kuruluşları tarafindan Latin Amerika ülkelerine kalkınma stratejisi bağlamında empoze edilen bir takım politika ve şartlarla ilişkiliyken zamanla Washington tarafından tüm dünyada kalkınmayı fonlamanın şartı olarak dayatılan politikalarla ilişkilendirilmeye başlandı. Williamson'1n da kabul ettiği gibi Washington kelimesinin kavramda kullanılmasının nedeni bu politikaların ABD tarafından oluşturulup tüm dünyaya empoze edilmesi ve politikaların ABD’nin kendi iç politikalarının bir benzeri olmasıdır (Marangos, 2014).

Washington uzlaşısı kapsamında empoze edilen politikalar GSYH büyümesine odaklı, tepeden inme, finansörlerin şartı olarak uygulanan ve dışa açık, ihracata yönelik ekonomi politikalarıdır. Washington uzlaşısı bağlamında kalkınma kişi başına düşen milli gelirin artmasıyla özdeşleştirilmiştir. Williamson (2008), Washington Uzlaşısı kapsamında uygulanan politikaları temel olarak şu şekilde ifade ediyor;

1) Mali disiplin

2) Kamu Harcama Önceliklerinin Yeniden Düzenlenmesi

3) Vergi Reformu

4) Serbest Faiz Haddi 
5) Serbest Döviz Kuru

6) Ticaretin Serbestleşmesi

7) Yabancı Doğrudan Yatırımların Serbestleşmesi

8) Özelleştirmeler

9) Deregülasyon

10) Mülkiyet Hakları

Williamson (2008), kendi orijinal listesindeki politikaların değiştirilerek tüm dünyaya uluslararası finansal kuruluşlar aracılığıyla empoze edildiğini ifade ediyor. Williamson kamu harcamalarının ve vergilerin azaltılmasını değil önceliklerinin yeniden düzenlenmesi gerektiğini belirtirken uygulamada kamu harcamalarını azaltmaya ve vergileri düşürmeye yönelik politikalar dayatılıyor. Ayrıca Williamson yabancı doğrudan yatırımların serbestleşmesini vurgularken, politikalar tamamen finansal serbestleşmeye yönelik uygulanıyor. $\mathrm{Bu}$ nedenlerden dolayı Washington uzlaşısı başta düşünüldüğünden daha serbest piyasa odaklı bir politika dayatma sürecine dönüşüyor. Williamson'ın orijinal listesi de dahil olmak üzere bu politikalar tam bir neoliberal manifesto olarak görülüyor ve çok büyük eleştiriler alıyor. Bu eleştirilerin yoğunlaşmasında 1990’lı yıllarda gelişmekte olan ülkelerin piyasalarını tamamen uluslararası sermaye hareketlerine açmaları ve küresel piyasaya gerekli altyapıları oluşturmadan eklemlenmelerinden kaynaklanan mali krizlerinde çok büyük etkileri oldu. Doğu Asya'da, Rusya'da, Türkiye'de ve Meksika gibi Latin Amerika ülkelerinde yaşanan krizler iddia edilen gelişmekte olan ülkelerin finansal serbestleşme ile daha büyük yabancı sermaye girişlerinden önemli faydalar sağlayacağı varsayımının çökmesine neden oldu (Birdsall ve Fukuyama, 2011). 


\section{M.KAYADUVAR - İ.ERGUN}

Washington uzlaşısı kapsamında uygulanan politikalar krizlerin etkisiyle büyük oranda itibarlarını kaybettiler. Bu duruma neoliberal politikaları uygulayan gelişmekte olan ülkeler beklenilen büyüme oranlarını yakalayamazken, bu politikaları uygulamadan yüksek büyüme oranı yakalayan ülkelerin de örneğin Çin, Hindistan gibi etkisi oldu (Öniş ve Şenses, 2005). Amerikan tarzı neoliberal sistem tam olarak itibarını kaybetmese de en azından egemen model olmaktan çıktı ve Washington Uzlaşısı'nın ekonomist Arvind Subramanian tarafından 'dış finansman fetişizmi' olarak adlandırılan finansal serbestleşme tutkusunun bankalar üzerinde yeterli denetimi sağlayacak yapılardan oluşan düzenleyici bir sistem olmadan uygulanmasının krizlere neden olduğu ve kurumların ön plana çıkartılması gerekliliği ön plana çıktı (Birdsall ve Fukuyama, 2011). Ayrıca Washington Uzlaşısı'nın ekonomik etkinliği ve verimliliği ön plana çıkaran yaklaşımının yoksulluk, sosyal haklar ve toplumsal gelir eşitsizlikleri üzerinde büyük tahribat yarattığı sıkça ifade edilmeye başladı. Uygulanan neoliberal politikaların yarattı̆̆ olumsuz etkilerin toplumsal hoşnutsuzlukları artırdığı ve toplumsal patlamalara ve mücadelelere yol açabileceği düşüncesi güç kazanmaya başladı.

$\mathrm{Bu}$ gelişmeler 1şı̆̆ında, neoliberal reçetelere yönelik eleştirilerin de yoğunlaşmasına karşı1lı daha geniş bir kalkınma anlayışının oluşturulmasına yönelik bir tutum ön plana çıktı. Bu yeni anlayış kapsamında yapısal uyum ve istikrardan vazgeçilmezken kalkınmanın sosyal boyutlarını da içeren ve katılımcılık vurgusunu öne çıkaran yeni bir çerçeve oluşturuldu. Bu bağlamda Dünya Bankası tarafından 1999 yılında "Kapsamlı Kalkınma için Çerçeve" (KKÇ) başlatıldı ve Washington uzlaşısı bağlamında ortalama gelirin artmasıyla özdeşleştirilen kalkınma daha geniş bir anlam kazandı. KKÇ’nin başlatılma gerekçesi olarak yoksulluktaki artış ve gelişmekte olan ülkelerin büyüme beklentilerini karşılayamamış olması 
ifade edilmiştir (Yavuz, 2007). KKÇ'nin Dünya Bankası'nın o döneme kadar uyguladığı politikalara karşı bir özeleştirisi olduğu sıklıkla ifa edildi. $\mathrm{Bu}$ yeni çerçeve ile Dünya Bankası kalkınmanın iki yüze sahip bir madalyon olduğunu ve bir yüzünün ihmal edildiğini kabul etti. Dünya Bankası'nın 1999 yılındaki başkanının kendi ifadesiyle “madalyonun bir yüzünde makro ekonomik kriterler, diğer yüzünde ise toplumsal, yapısal ve beşeri unsurlar yer almaktadır ki yapılması gereken her iki yüzü birlikte değerlendirmektir” (Wolfensohn, 1999: 5). Dünya Bankası'nın bu yaklaşım değişikliği ve bu yeni anlayış çerçevesinde bir kalkınma programı önermesi Post-Washington Uzlaşısı'na geçişin somut bir göstergesi olarak kabul edildi (Yavuz, 2007).

Post-Washington Uzlaşısı'nın ortaya çıkışında Dünya Bankası'nda baş ekonomist olarak görev yapan Nobel ödüllü iktisatçı Stiglitz çok önemli bir role sahiptir. Post-Washington uzlaşısının teorik alt yapısını oluşturulmasında merkezi bir öneme sahiptir. Stiglitz'in Washington Uzlaşısı'na bir alternatif olarak sunduğu Post-Washington Uzlaşısı'nın en temel unsurlarından biri devletin kalkınma sürecindeki rolüne vurgu yapılmasıdır (Öniş ve Şenses, 2005). Bu anlayış değişikliğinin en temel nedeni Stiglitz'in de ortaya koyduğu şekliyle Washington Uzlaşısı'nın kalkınma olgusunu ve gelişmekte olan ülkeleri anlama konusunda başarısız olmasıdır. $\mathrm{Bu}$ başarısızlığın sebepleri ise kalkınma anlayışının sadece GSYİH artışına odaklanması ve kalkınmanın diğer faktörlerini yaşam standartlarının yükselişi, demokrasinin gelişimi vb. göz ardı etmesi ve piyasanın daha verimli çalıştığı düşüncesinden hareketle devleti piyasanın işleyişinden dışlayıcı anlayışıdır (Stiglitz, 2007). Washington Uzlaşısı ile ortaya konan neoliberal ortodoksinin aksine Stiglitz'in Washington Uzlaşısı Artı (Washington Consensus Plus) olarak da kavramsallaştırdığı PostWashington Uzlaşısı serbest piyasayı savunurken, piyasa 


\section{M.KAYADUVAR - İ.ERGUN}

eksiklikleri/başarısızlıkları ve işlem maliyetleri nedeniyle piyasanın da verimsiz sonuçlar doğurabileceğini kabul ederek bu verimsizliklerin aşılmasında devletin müdahalesinin gerekli olduğunu öne çıkartmaktadır. $\mathrm{Bu}$ düşünceden hareketle devletin piyasayı tamamlayan bir unsur olduğunu birbirinin ikamesi değil, tamamlayıcısı olduğunu kabul etmektedir (Stiglitz, 2005, 2007). Özellikle devletin düzenleyici rolüne ve yönetişime vurgu yapılmaktadır. $\mathrm{Bu}$ şekilde bilgi asimetrilerinden ve işlem maliyetlerinden kaynaklanan piyasa eksikliklerinin önüne geçileceği, piyasaların verimli çalışmasının sağlanabileceği öne sürülmektedir (Fine, 2003).

Fakat bu anlayış değişikliği ile Washington Uzlaşısı'nın temel varsayımlarının ve neoliberal doğasının değiștiğini söylemek mümkün değildir (Marangos, 2007, 2008, 2014, Fine, 2003, Saad-Filho, 2010, Williamson, 2007). Yapılan değişiklikler ile kurumların ve yönetişimin ön plana çıkarılmasının nedeni neoliberal politikalar ile istenilen büyüme hedeflerinin tutturulamamasının ve mali krizlerin sebebi olarak kurumsal altyapılardaki eksiklerin kabul edilmesidir. Diğer bir ifadeyle, sorunların nedeni temel varsayımlarda aranmamakta, kurumsal altyapı yetersizlikleri günah keçisi ilan edilmektedir. Zaten Fine'ın ve Rodan'ın da vurguladığı gibi Post-Washington Uzlaşısı'nın devletin piyasaya müdahalesine yaklaşımı çok temkinlidir. Piyasaya müdahalenin ancak tek bir gerekçesi olabilir; piyasa aksaklığının ortaya çıkması (Fine, 2001, Rodan, 2004).

Yukarı da değinildiği gibi neoliberal politikaların tıkandığı bir dönemde tıkanıklığı açmaya yönelik politikalar öneren Post-Washington Uzlaşısı temelde Washington Uzlaşısı'ndan çok da farklı değildir. Post-Washington Uzlaşısı ile temelde neoliberalizmin varlığı, başka araçlarla donatılmış şekilde devam etmektedir (Saad-Filho, 2010, Williamson, 2007, Marangos, 2007, 2008, 2014, Fine, 2003). Neoliberal politikaların neden olduğu sosyal tahribatların görünümünü azaltarak neoliberal sistemin sürdürülebilirliğini 
sağlamak için kalkınmanın sosyal boyutuna vurgu yapmaktadır. Asıl amaç neoliberalizmin sebep olduğu toplumsal problemleri çözmek değil, sistemin devamını sağlayacak değişiklikleri yapmaktır. Bunu yaparken de neoliberal politikalara sosyal bir görünüm verme amacındadır. Şenses'in ifadesiyle uluslararası finans kuruluşlarının neoliberal sistemin "insani bir çehreye" kavuşturulmadan sürdürülemeyeceğini anlamış olmaları yoksulluk, toplumsal eşitsizlikler ve sosyal güvenlik gibi konulara da odaklanmalarına neden olmuştur (2009). Saad-Filho’nun “insani bir çehre altında yapısal uyum” (2010; 5) diye kavramsallaştırdığı bu durumu Cammack (2004) yoksulluğu azaltma gerekçesi altında gelişmekte olan ülkelerin piyasalarının etkin çalışmamasının önündeki engelleri kurumları ön plana çıkartarak kaldırmak olarak yorumlamaktadır.

Neoliberalizme sosyal bir yüz kazandırma düşüncesi bağlamında 2000’li yıllarda yoksulluk konusuna olan ilgi artmış başta Dünya Bankası ve Birleşmiş Milletler olmak üzere küresel düzeyde yoksullukla mücadele konusu gündemde önemli bir yer tutmuştur. İleriki bölümde bu çerçevede Dünya Bankası'nın ve özellikle Birleşmiş Milletler'in 2000’li yıllarda yoksulluk konusuna ilişkin faaliyetlerine değinilecek bu çalışmanın asıl konusu olan Birleşmiş Milletler 2015 Sonrası Kalkınma Gündemi PostWashington uzlaşısı bağlamında değerlendirilecektir.

\section{BM 2015 SONRASI KALKINMA GÜNDEMI}

1980’li ve 1990’lı yıllara damgasını vuran serbest piyasayı, finansal ve serbestliği savunan ve Washington Uzlaşısı olarak tanımlanan neoliberal politika paketi daha önce değinildiği gibi 1990’ların sonlarına doğru ciddi eleştirilere maruz kalmıştır. Bu politikalar sonucu Sapancalı'nın da ifade ettiği gibi yoksulluk hem gelişmiş hem de gelişmekte olan ülkeler için yapısal bir soruna dönüşmüş ve bu nedenle küresel bir problem haline 


\section{M.KAYADUVAR - İ.ERGUN}

gelmiştir (2001). Bu bağlamda neoliberal politikaların sürdürülebilirliğini sağlamaya yönelik birtakım değişiklikler yapılmış ve temel felsefesi değişmezken Washington Uzlaşısı'na sosyal bir yön ekleyen ve PostWashington Uzlaşısı olarak adlandırılan politika paketi ön plana çıkmıştır. Post-Washington uzlaşısı çerçevesinde yoksulluk konusuna olan ilgi küresel düzeyde çok artmış ve Dünya Bankası ve Birleşmiş Milletler yoksulluğa gündemlerinde çok önemli bir yer ayırmışlardır.

Dünya Bankası 2000/2001 Dünya Kalkınma Raporu'nu her onuncu yıl raporunu ayırdığı gibi yoksulluk konusuna ayırmıştır. Yoksulluğa Saldırı (Attacking Poverty) isimli raporda Dünya Bankası yoksulluk konusuna olan yaklaşımını değiştirdiğini ve artık yoksullukla daha geniş, kapsamlı ve çok boyutlu bir yaklaşımla mücadele edeceğini öne sürmüştür. Dünya Bankası'nın yeni yoksullukla mücadele stratejisinin üç temel ayağı; yoksullara yönelik yeni firsatlar yaratılması, yoksulların güçlendirilmesi ve risklere karşı güvenliğin artırılmasıdır (World Bank, 2001). Raporun detaylarına bakmaya gerek dahi olmadan, yoksulluk stratejisinin yoksulluğun nedenlerine odaklanmadan görünürdeki sonuçlarına odaklandığını söylenebilir. Diğer bir ifadeyle raporda yoksulların neden yoksul olduklarına değinilmeden, verili kabul edilen yoksulluklarının yeni firsatlar yaratılması ile yani piyasaya entegre edilmelerinin sağlanması ile, yoksulların bu entegrasyonu kolaylaştıracak şekilde güçlendirilmeleri ile yani çeşitli programlar aracılığıyla niteliklerinin artırılması ile ve risklere karşı güvenliğin artırılması ile yani bazı yoksullara yönelik koruma programları ile giderilebileceğine odaklanılmıştır. $\mathrm{Bu}$ raporda geçmiş raporlardan farklı olarak yoksulluğun ölçümünde günlük 1 dolar kriterinin yanında günlük 2 dolar kriteri ve UNDP’nin İnsani Gelişim Endeksi içinde bulunan bazı kriterlere yakın kriterler de kullanılmaya başlamıştır. Rapora göre 6 milyarlık dünya nüfusunun 2,8 milyarı günlük 2 doların altında bir 
gelirle yaşamaktadır, 1,2 milyar insan ise günlük 1 doların altında yaşamaktadır (WB, 2001).

Benzer bir şekilde Birleşmiş Milletler 2000 yılında 'Milenyum Kalkınma Hedefleri' (Millennium Development Goals) ile yoksullukla mücadele konusunda temel teşkil eden bir metin ortaya koymuştur. Milenyum Kalkınma Hedefleri, Eylül 2000 tarihinde toplanan zirvede kabul edilerek imzalanan Milenyum Deklarasyonu'ndaki eylem ve hedeflerden çıkarılmış, 2015 yılına kadar gerçekleştirilmesi hedeflenen 8 amaç ve 18 ölçülebilir hedeften oluşmaktadır (Bakınız Tablo 1).

Milenyum Kalkınma Hedefleri’ne bakıldığında yoksullukla ilgili olarak açıklanan 'Aşırı Yoksulluk ve Açlığı Yok Etmek' amacının Dünya Bankası'nın yoksulluk perspektifini yansıttığı söylenebilir (Tireli, 2009) çünkü BM ilk amacını şu şekilde açıklıyor:

- Günlük 1 doların altında yaşayan insanların toplam dünya nüfusuna oranını yarıya düşürmek

- Gençler ve kadınları da içine alacak tam ve verimli bir istihdamı sağlamak

- Açlık çeken insanların oranını yarı yarıya düşürmek 


\section{M.KAYADUVAR - İ.ERGUN}

Tablo 1. Milenyum Kalkınma Hedefleri

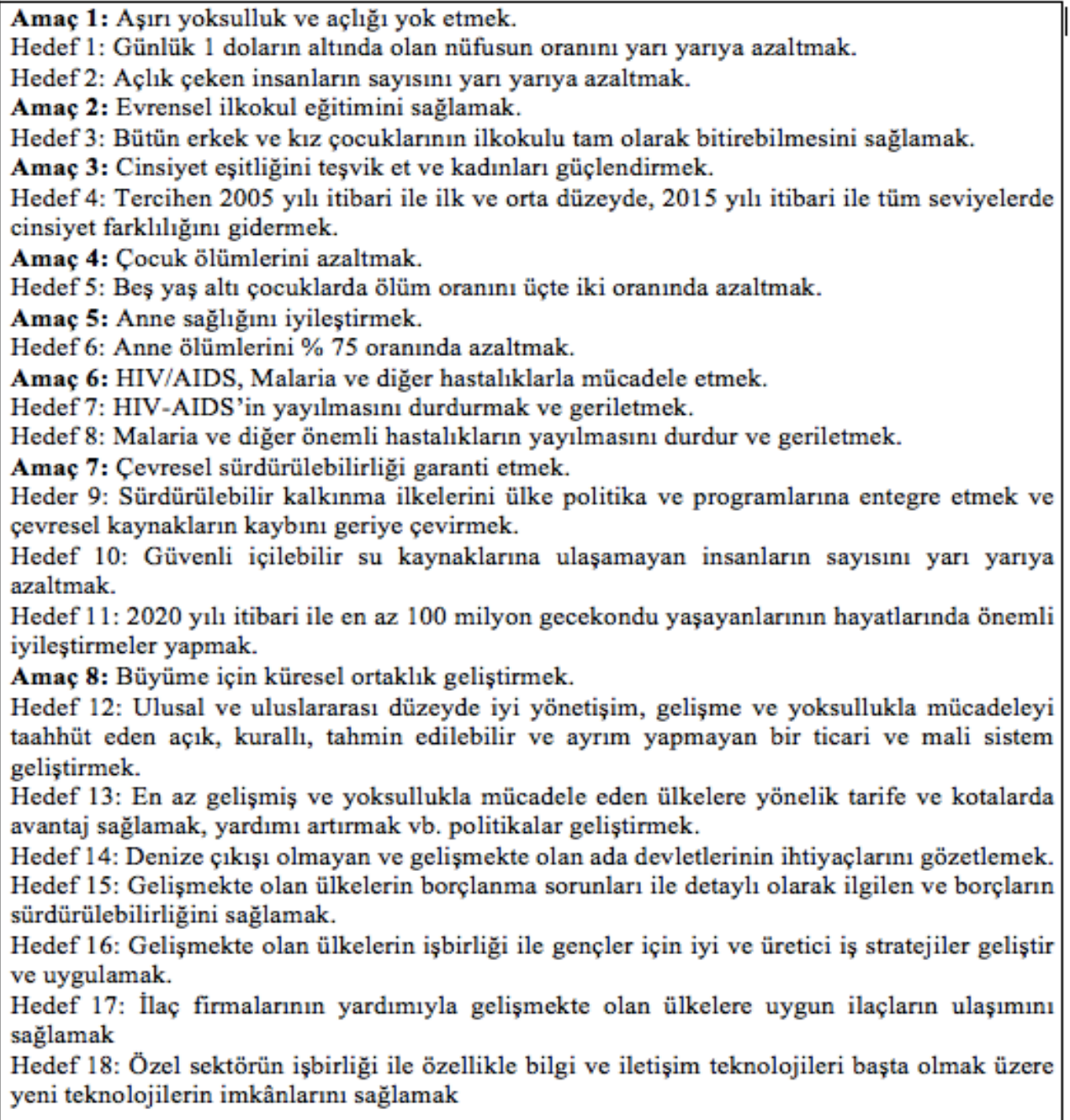

Kaynak: Birleşmiş Milletler Kalkınma Programı, 2000.

Görüldüğü gibi BM de Dünya Bankası'na benzer bir şekilde günlük 1 dolar kriterini kullanıyor diğer bir ifade ile mutlak yoksulluğa odaklanıyor ve yoksulların piyasaya entegrasyon ile yani istihdam edilmeleri ile yoksulluğa bir çözüm bulunabileceğini ileri sürüyor. Tireli'nin de ifade ettiği gibi amaçların bütününe bakıldığında çok boyutlu bir yoksulluk yaklaşımı kullanılmasına rağmen yoksulluk ayrı ayrı bağlamlarda, birbiriyle ilişki kurulmaksızın betimlenmektedir (2009) yani yoksulluk 
kavramsallaştırması çok boyutlu olmakla birlikte bütüncül bir yaklaşımdan uzaktır ve bu durum çözümlerin ayrı ayrı bağlamlara odaklanmasına sistemin bütününe yönelik değişiklik gerektirecek çözümlerin göz ardı edilmesine neden olmaktadır.

Milenyum Kalkınma Hedefleri Post-Washington uzlaşısı bağlamında ortaya çıkan yeni kalkınma anlayışının "hayata geçirilme aracı" (Eşinat, 2015: 14) olmuştur. $\mathrm{Bu}$ nedenle neoliberal politikalara insani çehre kazandırma düşüncesinin izlerinin görüldüğü bu hedeflerde de Dünya Bankası'nın yoksulluk raporunda olduğu gibi yoksulluğun sisteme içkin nedenlerine vurgu yapılmamaktadır. Serbest piyasa ekonomisi verili kabul edilirken sistemde yapılacak reformlar ile yoksulluk sorunuyla mücadele edilebileceği öne sürülmektedir. Bu durum kapitalist sistemin devamını tehdit eden yoksulluk sorununa karşı sosyal patlamalara sebebiyet vermeyecek oranda çözüm bulma gayretini yansıtmaktadır. Kapitalist sistem “düzenli olarak işlerini kaybeden ya da geçim kaynaklarının tehdit edildiğini gören suçsuz kurbanlar yaratan dinamik bir süreçtir” (Fukuyama ve Birdall, 2011: 48). Diğer bir ifadeyle kapitalizm sürekli olarak işsizlik ve yoksulluk yaratan bir sistemdir ve sisteme dair değişiklik yapmadan yoksullukla mücadele etmek sadece yoksulluğun görünen yüzünde etki doğurur. Bu nedenle BM Milenyum Kalkınma Hedefleri'ni yoksullukla tam bir mücadeleden çok kapitalist sistemin yani serbest piyasaya ekonomisinin sürdürülebilirliğine yönelik bir gayret olarak ifade edilebilir.

$\mathrm{Bu}$ argümanı destekleyen bir diğer gelişme ise ilk olarak BM 1995 Kopenhag Toplumsal Kalkınma Dünya Zirvesi’nde gündeme gelen 'Küresel Sözleşme' (Global Compact) adı verilen Birleşmiş Milletler oluşumudur. Özdek'in ifadesi ile paradoksal bir şekilde BM yoksullukla mücadeleyi insanlığın etik, sosyal, politik ve ekonomik bir zorunluluğu olarak ifade ederken bu zorunluluğu serbest piyasa ideolojisinin bir parçası olarak kabul 


\section{M.KAYADUVAR - İ.ERGUN}

etmiştir. Yani küresel serbest piyasa, temel ekonomi politikası olarak benimsenirken, yoksulluğun arttığı ve mücadele edilmesi gerekliliğine de vurgu yapılmıştır (2002). Küresel piyasa sistemi odaklı yaklaşım 1990’ların sonuna kadar devam etmiş ve 1999 yılında düzenlenen Dünya Ekonomik Forumu'nda BM Genel Sekreteri Kofi Annan sermaye liderlerini küresel piyasaya insani bir yüz vermeye çağırmıştır (Özdek, 2002). Bu gelişme Post-Washington Uzlaşısı'nın bir uzantısı olarak kabul edilebilir. Küresel Sözleşme kapsamında 2000 yılında BP, Shell ve Nike gibi uluslararası firmalar toplanmış ve şirket yurttaşlığı (corporate citizenship) bağlamında şirketlerin insan hakları, işgücü ve çevre konularında uymaları gereken hususları belirlemişlerdir (Özdek, 2002). Görüldüğü üzere Birleşmiş Milletler yoksulluk sorununa odaklanırken küresel sözleşme, şirket yurttaşlığı gibi Post-Washington Uzlaşısı'nın yansımaları sayılacak kapitalist ekonomiye sosyal bir yüz kazandırma gayretlerinin bir parçası olmaktadır. Özdek de benzer bir şekilde Birleşmiş Milletlerin yoksullukla mücadele vurgusunun şirket yurttaşlığı olgusuna meşruiyet kazandırmaya yönelik bir vitrin çalışmasının ötesinde bir mahiyet göstermediğini ifade etmektedir (2002).

Birleşmiş Milletler, Milenyum Kalkınma Hedefleri'nde Dünya Bankası'nın mutlak yoksulluk sınırı olarak belirlediği 1 dolar kriterini kullandığı için 2000’li yıllarda yoksulluk rakamlarında gerileme olduğunu müjdelemeye başlamıştır (Özdek, 2002). Ama bu kriter yoksulluğun küresel boyutunu gizlemektedir çünkü 1 dolar kriteri yoksulların azınlık olarak gösterilmesine olanak sağlamaktadır. 1 doların çok az üstünde gelir sağlayanlar bu kriter doğrultusunda yoksul kabul edilmemektedir. Bu kriter kullanılarak yoksulluk oranları manipüle edilmektedir. $\mathrm{Bu}$ şekilde Milenyum Kalkınma Hedefleri'ndeki hedeflere ulaşıldığı ileri sürülmektedir. Milenyum Kalkınma Hedefleri 2014 raporuna göre, aşırı 
yoksulluğu ve açlığı yok etme amacına ulaşılmıştır. Yoksulluk oranı 1990 ve 2010 yılları arasında yarı yarıya azalmış ama 2014 yılında 1,2 milyar insan hala aşırı yoksulluk içinde yaşamaktadır. Yani küresel açlık, hedef tarih olan 2015 'ten 5 yıl önce yarı yarıya azaltılmıştır. Gelişmekte olan bölgelerdeki çocukların yüzde 90’1 2014 yılı itibariyle ilkokul eğitimi alırken ve ilkokula giden kız ve erkek çocuklarının sayısındaki eşitsizlik azaltılmıştır. Tüm sağlık göstergelerindeki ilerlemenin yanında sıtma ve tüberküloza karşı mücadelede de kayda değer bir ilerleme görülmüştür. Bir çocuğun beş yaşından önce ölme olasılığı son yirmi yılda neredeyse yarı yarıya azalmıştır. $\mathrm{Bu}$, her gün 17 bine yakın çocuğun kurtarıldığı anlamına gelmektedir. İyileştirilmiş su kaynaklarına erişimi olmayan insan sayısını yarı yarıya indirme hedefine de ulaşılmıştır (United Nations, 2014). Ortaya çıkan olumlu küresel gelişmelere rağmen, Milenyum Kalkınma Hedefleri bölgeler arası ve bölgelerin kendi içindeki farklılıkların, eşitsizliklerin giderilmesinde yeterli başarıyı gösterememiştir. "Cinsiyet, yaş, etnik köken, ait olunan coğrafya ile ilgili özelliklere bağlı olarak aşırı yoksulluk içinde yaşayan binlerce insan 2000 ve 2015 yılları arasında yaşanan olumlu gelişmelere dâhil olamamışlar ve sistem dışı kalmışlardır" (Eşkinat, 2015: 8). Yoksulluk konusuna küresel bakış bölgesel başarısızlıkları gizleyen bir perde oluşturmaktadır. Yeni bir kalkınma programına ihtiyaç olduğu bölgesel ve yerel gelişmelere bakıldığında açıkça görülüyordu.

Milenyum Kalkınma Hedefleri 2015 yılına kadar gerçekleştirilmesi hedeflenen amaçlardan ve hedeflerden oluşuyordu. 2012 yılında Rio Zirvesi'nde Milenyum Kalkınma Hedefleri ile başlatılan işi bitirme ve başarılamayanları tamamlama kararı alındı (Eşkinat, 2015) ve 2030 yılına kadar aşırı yoksulluğu tüm dünyada ortadan kaldırma hedefi koyuldu. 2015 sonrası dönem için hedefleri belirlemek üzere küresel bir süreç başlatıldı ve tüm dünyadan hükümetler, sivil toplum kuruluşları, üniversiteler, özel 


\section{M.KAYADUVAR - İ.ERGUN}

sektör kuruluşları, araştırma kurumları ve yerel hükümetler ile fikir alışverişinde bulunuldu. 27 üyeden oluşan Seçkin Kişiler Üst Düzey Paneli (The high-level Panel of Eminent Persons) 2015 Sonrası Kalkınma Gündemi Raporu'nu hazırladı ve BM genel sekreteri Ban Ki-moon’a sundu.

Yeni bir Küresel Ortaklık: Sürdürülebilir Kalkınma Yoluyla Yoksulluğu Ortadan Kaldırmak ve Ekonomileri Dönüştürmek başlığını taşıyan rapor 2012'de Rio Sürdürülebilir Kalkınma Konferansı'nda kararlaştırılan 2030 yılına kadar aşırı yoksulluğu ortadan kaldırmak ve sürdürülebilir kalkınma hedefini gerçekleştirmek için evrensel bir gündemi ortaya koyuyor. Üst Düzey Paneli'nin eş başkanı sürdürülebilir kalkınma dönüşümü ile yoksulluğa son vermenin bizim jenerasyonumuzda mümkün olacağını ve bu iyimserlikle raporu hazırladıklarını ifade ediyor (UN, 2013). Bu raporda kalkınma gündeminin evrensel olması gerektiği vurgulanıyor ve 2015 sonrası hedeflerin hem gelişmiş hem de gelişmekte olan ülkelerde uygulanabileceği ifade ediliyor. Raporda Milenyum Kalkınma Hedeflerinin yoksulluğu azaltma hedefinde başarılı olurken, sürdürülebilir bir üretim ve tüketimin sağlanması noktasında birçok eksiğinin bulunduğu ifade ediliyor ve Milenyum Kalkınma Hedefleri'nin yoksulluğu azaltma hedefinin 2015 sonrası kalkınma gündeminde yoksulluğun her formunun sona erdirilmesi hedefine dönüştürüldüğüne vurgu yapılıyor. $\mathrm{Bu}$ bağlamda yoksullukla mücadele konusunda sosyal, ekonomi ve çevre politikalarının entegre edilmesinin sürdürülebilir bir kalkınma için gereklilik olduğu ortaya konuyor (Bakınız Tablo 2). 
Tablo 2. Sürdürülebilir Kalkınma Hedefler

Hedef 1: Her tür yoksulluğu, nerede olursa olsun sona erdirmek

Hedef 2: Açlı̆ğ bitirmek, gıda güvenliğini sağlamak, beslenme imkânlarını geliştirmek ve sürdürülebilir tarımı desteklemek

Hedef 3: İnsanların sağlıklı bir yaşam sürmelerini ve herkesin her yaşta refahını sağlamak

Hedef 4: Herkesi kapsayan ve herkese eşit derecede kaliteli eğitim sağlamak ve herkese yaşam boyu eğitim imkânı tanımak

Hedef 5: Toplumsal cinsiyet eşitliğini sağlamak ve kadınların ve kız çocuklarının toplumsal konumlarını güçlendirmek

Hedef 6: Herkes için suya ve sağlıklamaya erişimi ve suyun ve sağliklamanın sürdürülebilir yönetimini garanti altına almak

Hedef 7: Herkes için erişilebilir, güvenilir, sürdürülebilir ve modern enerji sağlamak

Hedef 8: Sürdürülebilir ve kapsayıcı ekonomik kalkınmayı sağlamak, tam ve üretici istihdamı ve insan onuruna yakışır işleri sağlamak

Hedef 9: Dayanıklı altyapı inşa etmek, sürdürülebilir ve kapsayıcı sanayileşmeyi ve yeni buluşları teşvik etmek

Hedef 10: Ülkelerin içinde ve aralarındaki eşitsizlikleri azaltmak

Hedef 11: Kentleri ve insan yerleşim yerlerini herkesi kucaklayan, güvenli, güçlü ve sürdürülebilir kilmak

Hedef 12: Sürdürülebilir tüketimi ve üretimi sağlamak

Hedef 13: İklim değişikliği ve etkileri ile mücadele için acil olarak adım atmak

Hedef 14: Okyanusları, denizleri ve deniz kaynaklarını sürdürülebilir kalkınma için korumak ve sürdürülebilir șekilde kullanmak

Hedef 15: Karasal ekosistemleri korumak, restore etmek ve sürdürülebilir kullanımını sağlamak, ormanların sürdürülebilir kullanımını sağlamak, çölleşme ile mücadele etmek,

toprakların verimlilik kaybını durdurmak ve geriye çevirmek ve biyoçeşitlik kaybını durdurmak

Hedef 16: Sürdürülebilir kalkınma için barış̧̧l ve herkesi kucaklayan toplumları teşvik etmek, herkesin adalete erişimini sağlamak, her seviyede etkin, hesap verebilir ve kucaklayıcı kurumlar inşa etmek

Hedef 17: Sürdürülebilir kalkınma için küresel ortaklığın uygulama araçlarını güçlendirmek ve küresel ortaklığı veniden canlandırmak

Kaynak: https://sustainabledevelopment.un.org/sdgs

Raporda 2015 sonrası hedeflerinin beş dönüşümü sağlayacağı ifade ediliyor;

- Aşırı yoksulluğu azaltma hedefinden hiç kimseyi geride bırakmamak hedefine gitmek

- Sürdürülebilir kalkınmayı kalkınma gündeminin merkezine yerleştirilmek,

- Ekonomileri herkesi dahil eden, büyümeyi ve istihdamı sağlayacak şekilde dönüştürmek 


\section{M.KAYADUVAR - İ.ERGUN}

- Herkese açık olan, iyi yönetişim ve barış içinde toplumlar sağlayan etkin ve hesap verebilir kurumlar kurmak ve iş birliği, eşitlik ve insan haklarına dayalı yeni bir küresel ortaklık oluşturmak

$\mathrm{Bu}$ beş dönüşümle birlikte dünyanın karşı karşıya olduğu iki büyük zorluğun üstesinden gelinebileceği belirtiliyor. Bunlardan ilki yoksulluk ikincisi ise sürdürülebilir kalkınmadır. Yoksulluk sona erdirilmeye çalışılırken gezegenimizin sahip olduğu kaynakların gelecek nesillere saklanması gerektiği düşüncesi raporun en temel vurgusudur.

Yoksullukla mücadele konusunda yeni kalkınma gündeminin yoksulluğun, dışlanmanın ve eşitsizliğin nedenleriyle ilgilenmesi gerektiği belirtiliyor ama rapor incelendiğinde yoksulluğun sisteme içkin sebeplerine yönelik bir vurgu yapılmadığı görülüyor. Yoksulluk bir hastalığın semptomu olarak ifade edilecek olursa yeni kalkınma gündemi hastalığın semptomlarını yok etmeyi amaçlayan ama hastalığın temel nedenini teşhis etmeyen bir tedavi olarak tanımlanabilir. Bu bağlamda raporda yoksulluktan çıkmanın yolu olarak firsatlar yaratılması ortaya konuyor yani yoksulların piyasayla ilişkilendirilmesinin önündeki engeller kaldırılarak yoksullukla mücadele edilebileceği ifade ediliyor. Başka bir ifade ile raporda yoksullukla mücadele konusunda liberal vurgular ön plana çıkartılıyor ve 'Eşit fırsat' (equal opportunity) yaratılarak yoksulların piyasaya entegre olmasının yani işe girmelerinin ya da girişimci olabilmelerinin sağlanabileceği belirtiliyor. Yani yoksullukla mücadele bu raporda da Milenyum Kalkınma Hedefleri ya da Dünya Bankası'nın raporları gibi kişisel düzeye indirgeniyor. Yoksulluk kişisel bir çözüm olarak tanımlandığı için eşit fursat yaratıldığında yoksulluğun çözülebileceği belirtiliyor. Yoksulluğun çözümünün piyasaya dahil olmakla ilişkilendirildiği görülüyor. $\mathrm{Bu}$ noktada hem neoliberal ekonomi politikalarına serbest ticarete, teknolojik gelişmelere, finansal istikrara, istihdam edilebilirliğin 
artırılmasına vurgu yapılıyor hem de neoliberal yönetişim mantığına yani hesap verilebilirlik, şeffaflık, iyi yönetişim gibi kavramlar ön plana çıkartılıyor.

Ekonomileri dönüştürmek amacı incelendiğinde raporda neoliberal ekonomilerin temelini oluşturan üretkenliğin, verimliliğin, yatırımların, işgücünün niteliğinin, girişimcilik desteklerinin, küçük ve orta işletmelere yönelik mikro kredilerin, ürün kalitesinin ve ürün çeşitliliğinin artırılmasının ve teknolojik yeniliklerin ön plana çıkartıldığ 1 görülüyor. Bu nedenle raporda kapitalist ekonomiye dair bir yapısal değişiklikten bahsedilmiyor aksine neoliberal dönemde geçerli sermaye birikiminin devamına yönelik politikalardan bahsediliyor. Ekonomide yapılacak bu değişikliklerin istihdamı artıran ve herkesi dahil eden bir ekonomik büyüme sağlayacağı ifade ediliyor. Yani yoksulluk ve işsizlikle mücadelede serbest piyasa ekonomisi ön plana çıkartılıyor. Kalkınma gündeminde toplumsal, ekonomik ve çevresel boyutların dahil edildiği bir yaklaşımın hakim olduğu söyleminin aslında görünüşte olduğu temelde kapitalist sistemin egemenliğinin devam ettiği söylenebilir. Milenyum Kalkınma Hedefleri’nde olduğu gibi Post-Washington Uzlaşısı bağlamında ön plana çıkartılan kapitalizmi sosyalleştirme olgusunun BM 2015 Sonrası Kalkınma Gündemi'nde de geçerli olduğu söylenebilir. Yoksulluğun tamamen ortadan kaldırılması hedefiyle yola çıkan yeni gündem yoksulluğun sisteme ilişkin nedenlerine vurgu yapmadan, 2000’li yıllarda dünya gündemine yerleşen çevre sorunlarına da değinerek serbest piyasa temelli çözümlere odaklanıyor. Sürdürülebilir kalkınma adı altında sürdürülebilir bir piyasa ekonomisi hedefleniyor. Neoliberal söylemler kullanılarak paradoksal bir biçimde neoliberal sistemin kronikleştirdiği yoksullukla mücadele edilebileceği vurgulanıyor. 


\section{M.KAYADUVAR - İ.ERGUN}

$\mathrm{Bu}$ bağlamda Sürdürülebilir Kalkınma Hedefleri kapsamında ortaya konan yoksullukla mücadele yolları Milenyum Kalkınma Hedefleri'nde de olduğu gibi gelir üstünden belirlenen mutlak yoksulluğu ortadan kaldırma hedefine ulaşılmasını küresel ölçekte sağlayabilir ama yoksulluğun sisteme içkin nedenleri hala var olmaya devam ettiği için sistem yeni yoksullar üretmeye devam edecektir. 2030 yılına gelindiğinde BM, Sürdürülebilir Kalkınma Hedefleri'ne ulaşıldığını müjdelese bile bu durum yoksulluğun görünen yüzü ve görünen nedenleriyle mücadele edilmesinden kaynaklanacaktır. Uygulanan neoliberal politikalar yeni yoksulluklar ve yeni gelir eşitsizlikleri doğuracaktır. Bu noktadan hareketle, yoksulluğun görünürlülüğü azaltılarak toplumsal patlamaları önlemeye yönelik kapitalizme insani bir yüz kazandırma gayretinin bu yeni kalkınma gündeminde de geçerli olduğu ifade edilebilir. Post-Washington Uzlaşısı'nın geçerli olduğu 2000'li yıllardaki hakim söyleme uygun olarak bu raporda da yoksullukla mücadele ön plana çıkartılarak piyasa temelli reformlara vurgu yapılmaktadir.

\section{SONUÇ}

Yoksullukla mücadele çok eski bir olgudur ama özellikle kapitalist ekonominin gelişmeye başladığ1 18.yüzyıl sonrası dönemde önemli bir gündem konusu olmuştur. Ekonomilere hakim olan liberal politikaların ciddi şekilde sorgulandığı 1929 krizinden ve II. Dünya Savaşı'ndan sonraki dönemde hakim olan Keynesyen refah devleti politikaları sayesinde yoksulluk görece azalmış ve yoksulluğa karşı ilgi azalmıştır. Yoksulluk az gelişmişlikle ilişsilendirilmiş ve üçüncü dünya ülkelerinin sorunu olarak kabul edilmiştir. 1970 yapısal kriziyle birlikte itibar kaybeden Keynesyen politikalar yerini serbest piyasa temelli neoliberal politikalara biraktı ve 1980’li yıllarda neoliberal politikaların sebep olduğu kitlesel işsizlik ve yoksulluk, yoksulluk olgusuna ilişkin ilginin artmasına sebep oldu. 
Yoksullukla mücadele uluslararası düzeyde gündeme geldi ve özellikle Dünya Bankası ve Birleşmiş Milletler olmak üzere uluslararası kuruluşlar yoksulluk konusuna eğildi.

Yoksulluğun kapsamı 1980’lerden itibaren genişletilirken yani mutlak yoksulluktan göreli yoksulluğa doğru bir eğilim görülürken, yoksullukla mücadelede serbest piyasa ekonomisi vurgusunda bir değişiklik görülmedi. 1990’larda egemen olan Washington Uzlaşısı kapsamında uygulanan neoliberal politikaların yarattığı olumsuz etkilere karşı önerilen ve PostWashington Uzlaşısı olarak tanımlanan yeni politika paketi kapitalist sisteme sosyal bir yön kazandırarak sistemin devamını sağlamayı amaçlıyordu. Bir başka ifadeyle 1990'ların sonuna doğru ciddi eleştirilere maruz kalan Washington Uzlaşısı ortaya koyduğu neoliberal ekonomi politikalarının devamını sağlayabilmek için yerini "kapitalizmin daha insani bir yorumu olan” (Eşkinat, 2015: 18) Post-Washington uzlaşısına bıraktı.

Bu bağlamda Dünya Bankası'nın yoksullukla mücadele yaklaşımında değişiklik yaşandı. Yoksulluğun kapsamı genişletilirken, sosyal politikalara dair vurgu arttı. Benzer bir şekilde Birleşmiş Milletler de Post-Washington Uzlaşısı kapsamında yoksullukla mücadele gündeminde sosyal politikaları ön plana çıkarttı. 2000 yılında Milenyum Kalkınma Hedefleri ile başlatılan yoksullukla mücadele programı, 2015-2030 dönemi için ortaya konan Sürdürülebilir Kalkınma Hedefleri’nin başlangıç noktasını oluşturdu. Bu nedenle bu çalışmanın ana konusu olan 2015 Sonrası Kalkınma Gündemi'nde Post-Washington Uzlaşısı'nın etkilerini görmek mümkündür. Yeni kalkınma gündemi 17 hedef ve bu süreci takip etmek üzere 169 gösterge belirlemekte ve yoksullukla mücadelede sürdürülebilir kalkınmayı ön plana çıkarırken sosyal, ekonomi ve çevre politikalarının entegre edilmesi gerekliliğini vurgulamaktadır. Programın yoksullukla konusunda ortaya koyduğu mücadele yollarına bakıldığında temelde serbest piyasa 


\section{M.KAYADUVAR - İ.ERGUN}

ekonomisine yönelik politikaların sosyal politika makyajıyla ifade edildiği görülüyor. Sürdürülebilir Kalkınma Hedefleri kapsamında yoksulluğun görünen nedenlerine odaklanıldığı için neoliberal politikaların yoksulluk doğurucu etkileri göz ardı ediliyor. Bu bağlamda yoksullukla mücadelede sisteme dair yapısal değişiklik önerilmeden piyasa temelli reformlar ön plana çıkartılıyor. Bu noktada yeni kalkınma gündeminin temel amacının Post-Washington Uzlaşısı kapsamında amaçlandığı şekilde sürdürülebilir bir kalkınma yerine sürdürülebilir bir piyasa ekonomisi olduğu ifade edilebilir.

\section{KAYNAKÇA}

BİRDSALL, N., \& FUKUYAMA, F. (2011), “The Post-Washington Consensus”, Foreign Affairs, 90(2), 45-53.

BUĞRA, A. (2008), Kapitaliz, Yoksulluk ve Türkiye’de Sosyal Politika, İletişim Yayınları, İstanbul.

CAMMACK, P. (2004), "What the World Bank Means by Poverty Reduction and Why it Matters?”, New Political Economy, 9(2), 189-211.

DERTLİ, N. (2007), Aktif İstihdam Politikaları - Eleştirel Bir Yaklaşım. (Yüksek Lisans Tezi). http://www.belgeler.com/blg/1amf/aktif-istihdampolitikalari-elestirel-bir-yaklasim-active-employment-policies-a-criticalapproach

EŞKINATT, R. (2015), "Binyıl Kalkınma Hedeflerinden Sürdürülebilir Kalkınma Hedeflerine”, EY International Congress on Economics II, Ankara.

http://ekonomikyaklasim.org/eyc2015/userfiles/downloads/_Paper\%2034.pd $\mathrm{f}$

FINE, B. (2001), Social Capital versus Social Theory: Political Economy and Social Sciencc at the Turn of tbe Millenium (Routledge Studies in Contemporary Political Economy), Routledge, Florence, KY.

JESSOP, B. (2002), The Future of the Capitalist State, Cambridge, Polity, UK. 
KARAÇAY, H. (2016), "Bretton-Woods Kuruluşları, New York Uzlaşısı Ve Yoksullukla Mücadele Politikaları”, Hacettepe Üniversitesi İktisadi ve İdari Bilimler Fakültesi Dergisi, 34(1), 93-114.

KONGAR, E. (2001), Küresel Terör ve Türkiye, Remzi Kitabevi, İstanbul.

KÖSE, A. H. (2004), "Dünya Bankası ve Benzer Kuruluşların Raporlarında Yoksulluk, Ne İçin, Ne zamandır Var?”, Toplum ve Hekim, 19(1), 23-26.

MARANGOS, J. (2007), "Was Shock Therapy Consistent with the Washington Consensus?”, Comparative Economic Studies, 49(1), 32-58.

MARANGOS, J. (2008), "The Evolution of the Anti-Washington Consensus Debate: From "Post-Washington Consensus" to "After the Washington Consensus”", Competition and Change, 12(3), 227-44.

MARANGOS, J. (2014), “A Keynesian Alternative to the Washington Consensus Policies for International Development”, International Journal of Trade and Global Markets, 7(1), 67-85.

ÖNIŞ, Z., \& ŞENSES, F. (2005), "Rethinking the Emerging Post-W ashington Consensus ”, Development and Change, 36(2), 263-290.

ÖZDEK, Y. (2002), Küresel Yoksulluk ve Küresel Şiddet Kıskacında İnsan Hakları, Yoksulluk, Şiddet ve İnsan Hakları (ss. 1-44), TODAİE İnsan Hakları Araştırma ve Derleme Merkezi, Ankara.

ÖZGÜR, B. (2004), Yoksullukla Mücadele mi, Yoksullarla Mücadele mi?. Almanak 2003, Sosyal Arastırmalar Vakfi Yayını, İstanbul.

RODAN, G. (2004), "Neoliberalism and Transparency: Political versus Economic Liberalism”, (Working Paper No. 112). http://researchrepository.murdoch.edu.au/id/eprint/13104/1/Neoliberalism_a nd_Transparency_Political_Versus_Economic_Liberalism.pdf

SAAD-FILHO, A. (2010), "Growth, Poverty and Inequality: From Washington Consensus to Inclusive Growth”, (Working Paper No. 100). http://www.un.org/esa/desa/papers/2010/wp100_2010.pdf 


\section{M.KAYADUVAR - İ.ERGUN}

SAPANCALI, F. (2001), "Yeni Dünya Düzeni Ve Küresel Yoksulluk”, Dokuz Eylül Üniversitesi Sosyal Bilimler Enstitüsü Dergisi, 3(2), 115-140.

STIGLITZ, J. E. (2005), "More Instruments and Broader Goals: Moving toward the Post-Washington Consensus", Wider Perspectives on Global Development, (Ed. Anthony Shorrocks), Palgrave Macmillan, New York, 16-48.

STIGLITZ, J. E. (2007), "Is There a Post Washington Consensus?", (Working Paper No. 128). http://policydialogue.org/publications/workingpapers/is-there-a-post-washington-consensus/

ŞENSES, F. (2009), Küreselleşmenin Öteki Yüzü, İletişim Yayınları, İstanbul.

TIRELİ, M. (2009), Küreselleşme ve Yoksulluk: Birleşmiş Milletler (UNDP) ve Dünya Bankası Göstergeleri Işığında Bir Analiz. (Uzmanlık Tezi).

http://sosyalyardimlar.aile.gov.tr/data/54291802369dc32358ee29ad/K\%C3 \%BCreselle\%C5\%9Fme\%20ve\%20Yoksulluk\%20Birle\%C5\%9Fmi\%C5\% 9F\%20Milletler\%20(UNDP)\%20ve\%20D\%C3\%BCnya\%20Bankas\%C4\% B1\%20G\%C3\%B6stergeleri\%20I\%C5\%9F\%C4\%B1\%C4\%9F\%C4\%B1nd a\%20Bir\%20Analiz\%20M\%C3\%BCnir\%20Tireli.pdf

UNITED NATIONS. (2013), “A new global partnership: Eradicate poverty and transform economies through sustainable development”, Final Report of the UN High-Level Panel of Eminent Persons on the Post-2015 Development Agenda. United Nations, New York.

UNITED NATIONS. (2014), The Millennium Development Goals Report, United Nations, New York.

UNDP. (2006), Milenyum Gelişme Amaçları. http://www.undp.org/mdg/

UZUN, A. M. (2003), "Yoksulluk Olgusu ve Dünya Bankası”, C.Ü. İktisadi ve İdari Bilimler Dergisi, 4(2), 155-173.

WILLIAMSON, J. (2007), "Shock Therapy and the Washington Consensus: A Comment”, Comparative Economic Studies, 49(1), 59-60. 
WILLIAMSON, J. (2008), “A Short History of the Washington Consensus”, The Washington Consensus Reconsidered (ss.14-30). Oxford University Press, Oxford.

WORLD BANK. (1978), World Development Report 1978: Prospects for Growth and Alleviation of Poverty. World Bank, Washington D.C.

WORLD BANK. (2001), World Development Report, 2000/2001: Attacking Poverty. World Bank, Washington D.C.

WOLFENSHON, J. D. (1999), A Proposal for a Comprehensive Development Framework. http://siteresources.worldbank.org/CDF/Resources/cdf.pdf

YAVUZ, G. (2007), "Washington Uzlaşması Sonrasında Dünya Bankasından Bir Açılım Önerisi: "Kapsamlı Kalkınma için Çerçeve”", İktisadi ve İdari Bilimler Fakültesi Dergisi, 9(3), 1-16.

ZAPÇI, F. Ç. (2002), "Sosyal Riski Azaltma Projesi: Azaltmak m1, Zengini Yoksuldan Korumak mı?”, A.Ü. SBF-GETA Tartışma Metinleri, (51).

http://www.tr.undp.org/content/turkey/tr/home/library/mdg.html, (06.01.2015).

https://sustainabledevelopment.un.org/sdgs (20.01.2018). 